\title{
The Effect of Global Financial Crisis on the Financial Performances of Commercial Banks of Ethiopia
}

\author{
Minyahil Assefa \\ Department of Accounting and Finance, Jigjiga University, Ethiopia, PO box 1020
}

\begin{abstract}
The 2007 financial crisis, triggered at the United States of America, affected many financial institutions around the world. In Ethiopia, some scholars argue that Commercial banks of Ethiopia (CBE) are not vulnerable for global financial crisis. Because, Commercial banks of Ethiopia are owned by state and domestic investors and the country does not allow foreign banks to operate in the country. In line with this argument, this study sought to investigate the effect of global financial crisis on the financial performances of commercial Banks of Ethiopia. The study used judgmental sampling method, taking in to account the age and accessibility of complete audited financial statements. The sample size of the study was two state owned and five private commercial banks. The study dominantly used secondary data. So as to triangulate results, the study also employed primary sources of data. To measure and analyze performance of commercial banks during the periods 2004-2010, CAMEL model and SPSS statistical tools were employed. The study found that the banks had had liquid and quality asset during the crisis. But among the growth mean deference of six variables of international banking related activities, only two variables (Deposit in Foreign Banks and Gain from Foreign Currency Translation and Exchange) had positive growth mean during the global financial crisis; the change was not statistically significant at $5 \%$ significance level. Whereas loan dispersed for importers (LI), interest income from foreign deposit, ROA, total revenue from international banking actives had been decreased by $214 \%, 217 \%, 16 \%$ and $39 \%$ respectively. These changes were statistically significant at $5 \%$. Thus the study concluded that, despite CBE were owned by state and domestic investors and international banks has been prohibited to operate in Ethiopia, the financial crisis significantly affected the financial performances of Ethiopia banking industry.
\end{abstract}

Keywords: Global Financial crisis, financial performance, commercial banks of Ethiopia, CAMEL

DOI: $10.7176 /$ RJFA/10-22-01

Publication date: November $30^{\text {th }} 2019$

\section{Introduction}

Banks serve as back bone to the economic growth of countries, which facilitate the proper utilization of financial resources by intermediating deficit and surplus unites. But, banks are exposed to a variety of risks that are growing more complex now a days. Once the system failed, the whole economy will collapse as the economic down turn of 2007 which was resulted from financial system failure in United States of America which was spread out widely around the world. Therefore these factors increasingly urge the need of more frequent banking examination particularly on their performance. The measurements of commercial bank performance have been researched well and received increased attention over the past years (for example Kouser, 2012; Reddy, 2012; Ashamu, 2012; Kumbirai and Webb (2010), Prasad, 2012; Webb, 2003; Tarawneh, 2006; Kiyota, 2009; Samad, 2004).

The crisis, although, started as a result of events in America housing market, it has spread to all regions of the world with direct consequences on global trade, investment, remittances, exchange rates and growth. Adamu, (2009) state that around the world stock markets have fallen, large financial institutions have collapsed or been bought out, and even government in the wealthiest nation have had to come up with rescue packages to bail out their financial system. Ashamu (2012) declared that the impacts of this global financial crisis on Africa are both direct and indirect. The direct effect was felt mostly through the financial sector.

In Ethiopia, some scholars argue that Commercial banks of Ethiopia are not vulnerable for global financial crisis. They usually put the following two reasons. First, Commercial banks of Ethiopia are owned by state and domestic investors. Second, the country does not allow foreign banks to operate in the country. On the other hand, others argued that banks of Ethiopia are not totally guaranteed from risks in international financial crisis. Because, today the banks are aggressively involve in international banking activities and strongly linked with foreign banks throughout the world. International banking operations contributed significantly to the banks' total income through earnings on foreign exchange dealings and commission and service charges on imports and outward money transfers. For example, Wegagen bank and Bank of Abyssinia earned 463.3 million birr or 55\% of its total income and 300.8 million birr or $49 \%$ of its income from International Banking Activities (IBA) respectively in $2010^{1}$. Furthermore, commercial banks of Ethiopia maintain good business relationships with various well-known international banks throughout the globe 1.

\footnotetext{
${ }^{1}$ National bank of Ethiopia annual report in 2011.
} 
However, as far as the researcher knowledge, there is scanty research that had been done on the overall commercial banks performance during the global financial crisis and its effect. Thus the primary objective of this study was to examine the effect of the Global financial crisis on the performance of commercial banks of Ethiopia.

\section{Null Hypothesis}

$\mathrm{H}_{\mathrm{o} 1}$ There is no significant change on the growth of Return on Asset before and during the crisis

$\mathrm{H}_{\mathrm{o} 2}$ There is no significant change on the growth of loan for Importers before and during the crisis

$\mathrm{H}_{03}$ There is no significant change on the growth of Interest Income from Foreign Deposit before and during the crisis

$\mathrm{H}_{04}$ There is no significant change on the growth of Total Revenue from International Activities before and during the crisis

$\mathrm{H}_{05}$ There is no significant change on the growth of Gain from Foreign Currency Translation \& Exchanges before and during the crisis.

\section{Literature review}

\subsection{Models for evaluating Bank Performance}

Different scholars have conducted researches on performance evaluation of commercial banks. Various techniques of evaluations have also been developed so far. Financial ratio analysis, CAMEL and the later CAMELS, Data Envelopment Analysis (DEA model), Analytical Hierarchy Process (AHP) are some of the methods used by scholars. This study employed CAMEL model, because is used to be more appropriate over the others.

\subsection{Overview of the Global Financial Crisis}

As of Osakwe (2010) the financial crisis started in the United States in 2007 and involved financial institutions in many developing countries. It was only when the crisis turned into a global economic recession that developing and emerging -market economies were affected, mainly through the trade channel, and in some cases through workers' falling remittances. In many developing countries, the economic consequences of these indirect effects were as severe as the direct effects were on developed countries. The worldwide recession, the first since the Second World War, led to a reduction of world gross domestic product (GDP) by 0.6 per cent in 2009. In the absence of countercyclical responses, the slump could have been much stronger. In 2009 global GDP growth was5.8 percentage points lower than in 2007, and the downturn in emerging and developing countries was almost the same as in developed countries (IMF, 2010). Countries constituting the Commonwealth of Independent States (CIS) and those of Central and Eastern Europe (CEE) were the most severely affected, their GDP growth rates falling by an average of 15.2 percentage points between 2007 and 2009. The corresponding figures for Latin America and sub - Saharan Africa were 7.6 and 4.8 percentage points respectively. In general, countries with large current -account deficits or surpluses, and those with large fiscal deficits prior to the crisis suffered much greater output losses than others. Even in developing Asia growth rates dropped by 4 percentage points between 2007 and 2009.

Ashamu (2012) examined the impact of global financial crises on the Nigeria banking system using survey. The study revealed that the financial crisis has caused depression of the Nigerian capital market and drop in the quality of part of the credit extended by banks for trading in the capital market, exchange rate risk tightening of liquidity, greater loan-loss provisioning, slower growth rate of banks' balance sheet in response to the crisis and higher provisioning leading to lower profitability among others. Karande, S.B (2012) examine the impact of global financial crisis on Indian banks using selected financial ratios. The study found that, hence India banks maintain appropriate adjustments to their portfolios and ensuring sound assets quality, the crisi s did not impose significant impact.

Uganda. Mwega F. M. (2010) investigated the impact of global financial crisis on Kenya's economy using descriptive method. The paper has addressed a whole range of issues. On the banking system, for example, it looks at a number of indicators and he concludes that the None-Performing Loons (NPLs), Return on Asset and Liquidity of the banks seem quite sound and have not been affected substantially by the crisis. However, financial statements for the first half of 2009 show a sharp decline in banks' profitability.

Kumbirai and Webb (2010) investigated the performance of South Africa's commercial banking sector for the period 2005-2009. Financial ratios are employed to measure the profitability, liquidity and credit quality performance of five large South African based commercial banks. The study found that overall bankperformance increased considerably in the first two years of the analysis. A significant change in trend is noticed at the onset of the global financial crisis in 2007, reaching its peak during 2008-2009. This resulted in falling profitability, low liquidity and deteriorating credit quality in the South African Banking sector. 


\section{Research Design}

The primary objective of this study is to investigate the effect of global financial crisis on the financial performances of commercial Banks of Ethiopia. Hence, to achieve this objective survey strategy of inquiry particularly longitudinal type employed. Because survey allows economy of accessing data that may not be available from other sources; being able to identify attributes of a large population from a small group of individuals (Babbie 1998, Fowler 2010)

Although accounting data in financial statements is subject to manipulation and financial statements are backward looking, they are the only detailed information available on the bank's overall activities (Sinkey, 2002). Furthermore, they are the only source of information for evaluating the firm's potential to generate satisfactory returns and achieving the interest of stock holders in future. Hence, this study is mainly used secondary data drawn from the annual audited financial statements and annual reports of the banks.

The population of the study were all commercial banks operating in Ethiopia. According to National Bank of Ethiopia, there are two national and fifteen private commercial banks are operating in the country as of December, 2012. The study used judgmental sampling method, based on the age and accessibility of complete audited financial statements. As a result a sample frame of eight commercial banks were selected, representing two state owned banks (Commercial bank of Ethiopia and Construction \& Business bank) and six private banks (Awash international bank, Dashen bank, Bank of Abyssinia, Wegagen bank, Nib International bank and United bank). Hence the sample size of the study was two state owned banks and the other five private commercial banks.

\subsection{Variables}

The following section explain the major components of CAMEL and variables related with international business activities that are used in this study.

Capital adequacy: Capital Adequacy reflects the overall financial condition of the banks. It also indicates whether the bank has enough capital to absorb unexpected losses. Capital Adequacy ratio acts as an indicator of bank leverage. The main components of this ratio are,

Total Debt to Total asset: This ratio indicates the degree of leverage of a bank. It indicates how much of the bank business is financed through debt and how much through equity. Higher ratio indicates less protection for the creditors and depositors in the banking system. Total capital to Risk-Weighted Assets: it indicates the riskiness of asset employed by the bank. Tier 1 Capital to total assets: it is the ratio of shareholders equity to total asset

Assets quality: This indicates what types of advances the bank has made to generate interest income. The ratios necessary to assess the assets quality are: Allowance for doubtful loans to total assets: This ratio discloses the efficiency of bank in assessing the credit risk and, to an extent, recovering the debts. It is the ratio of allowance for doubtful loans and total assets. Allowance for doubtful loans to loans outstanding: It is the most standard measure of assets quality measuring the net non-performing assets as a percentage to net advances. NonPerforming Loans (NPLs) to total loans outstanding: this measure the loss incurred due to poor loon quality. Total Investment (TI) To Total Asset (TA): it indicates the proportion of banks asset used in other investment instead of loan disbursement.

Management efficiency: The ratio in this segment involves subjective analysis to measure the efficiency and effectiveness of management. The ratios used to evaluate management efficiency are described as: Total advances to total deposits: this ratio measures the efficiency and ability of the bank's management in converting the deposits available with the bank excluding other funds like equity capital into high earning advances. Earnings before Tax (EBT) to Total Revenue (TR): It rate Managers' efficiency in reducing costs that would be incurred to generate bank's revenue. Total revenue per employee (TR/No.Em): it shows the productivity of human force of bank. It is used as a tool to measure the efficiency of employees of a bank in generating business for the bank. Higher the ratio, the better it is for the bank. Earnings before Tax per employee (EBT/No.Em): This shows the surplus earned per employee.

Earning quality: It basically determines the profitability of bank and explains its sustainability and growth. The following ratios are used to explain the quality of banks earning. Return on assets: This ratio measures return from assets employed or the efficiency in utilization of assets. The higher return on asset the more efficient in asset utilization. Return on equity: measures the efficiency in utilizing the bank equity. The higher return on equity the more efficient in equity utilization. Interest income to Total Revenue (II/TR): Shows the share of banks interest income earned from advances out of the total revenue. Spread to total assets (SP/TA): greater spread means that the banks keep their interest low on deposits and high on advances to increase their earnings capacities. This ratio indicates the percentage of spread earned from the total asset utilized. The higher this ratio the more profitability and efficient in utilizing its deposit and advances. Total Revenue includes income both from advances and other banking activities. 6 Spread is the difference between the interest income and interest expenses.

Liquidity: Risk of liquidity is curse to the image of bank. Bank has to take a proper care to hedge the liquidity 
risk. The following ratios are used to measure the liquidity under the CAMEL Model. They are: Liquid assets to total assets (LA/TA): It measures the overall liquidity position of the bank. The higher this ratio indicates the more solvent. Liquid assets to demand deposits (LA/DD): This ratio measures the ability of bank to meet the demand from depositors in a particular year. To offer higher liquidity for them, bank has to invest these funds in highly liquid form. Liquid assets to total deposits (LA/TD): This ratio measures the liquidity available to the total deposits of the bank.

Loan for Importers (LI): Indicates the availability of foreign currency to finance importers

Interest Income from Foreign Deposit (IIFD): Indicates the interest income earned from abroad banks?

Total Revenue from International Activities (TRIA): Indicate the overall revenue generated from international banking activities.

Gain from Foreign Currency Translation \& Exchanges (GFCTE): Indicate revenues earned from foreign currency dealings \& translation at balance sheet date.

Return on Asset (ROA): Indicate the changes in ROA during the global financial crisis.

\subsection{Data Analysis Method}

This study primarily used CAMEL model to measure and analyze performance of commercial banks between the periods 2004-2010. This study is a type of time serious analysis which used SPSS statistical tools.

To examine the impact of global financial crisis on the performance of commercial banks of Ethiopia, the researcher identified six variables that are exposed to the global financial crisis. Namely; Total Revenue Earned from International Banking Activities, Loan Disbursed to Importers, Deposit in Foreign Banks, Interest income from Foreign Deposit, Gain from Foreign Currency Translation and Exchange and Return on Asset.

Then these variables growth mean classified in to two categories i.e. before the crisis (2004-2006) \& during the crisis (2007-2009). Because, the recent global financial crisis begun in $2007 \&$ reaches its pack during 2008 and 2009 (Osakwe, 2010). Therefore, to test whether the difference in performance of the banks before the crisis (2004-2006) was statistically different or not during the crisis (2007-2009), a Paired-Samples T test adopted. Because the paired-samples $t$ taste is appropriates whenever two related samples means are to be compared. The appropriateness of the parametric tests has been checked considering assumptions of normality, none extreme or outlying values and independent of the order of observation (Field, 2005). This implies that difference scores are assumed to follow reasonably normal distribution, especially with respect to skeewnes.

Hence, the normality of the data had been checked using the Kolmogorov-Smirnov tests of normality. Also variables were carefully tested with extreme or outlying values. Furthermore Runs Test procedure was adopted to check the assumption that the value of the test variable is independent of the order of observation. Fortunately, all the six variables hold these assumptions. Inferences about the hypothesis are made by looking at test statistics and critical values associated with the growth mean. If $t$-value $\leq \alpha$, reject the null hypothesis. If $t$-value $>\alpha$, do not reject the null hypothesis.

\section{Analysis and Discussion of Results}

This chapter deals with the analysis and discussion of the results of the study. The chapter begins with the time series analysis and presentation of the descriptive statistics for CAMEL variables.

These are presented using the means and standard deviation including the minimum and maximum values for each of the variables. This is then followed by the Hypotheses test using Paired-Samples $\mathrm{T}$ test for six international banking activities variables.

\subsection{Descriptive Statistics}

Capital Adequacy: Total capital to Risk-Weighted Assets ratio decrease from $16.5 \%$ in 2005 to $8.9 \%$ in 2010 . The possible reason for the gradual decrease is, following the entrance of new banks and innovation of new technology, competition among banks becomes strong. As a result banks were forced to take certain risky investments (off balance sheet activities) to maintain their competitive positions. In addition, as the economy grew, credit demands incredibly increased and banks were able to provide more loan and advances than ever. Consequently, this enlarged the RWA and eroded the asset quality of commercial banks of Ethiopia during 2005 and 2010. But the amount of capital adequacy is more than the requirements of both National Banks of Ethiopia (NBE) and Basel requirements, which is $8 \%$.

Regarding total debt to total asset ratio was between $87.7 \%$ and $85.6 \%$. This tell us, on average $87.7 \%$ of Ethiopian Commercial banks assets are financed by debt and the contribution of shareholders is less than $13 \%$. It seems that the banks are excessively levered. In fact, banks are highly levered industry throughout the world; this is not a surprise or unique scenario for Commercial Banks of Ethiopia.

Asset Quality: the ratios of asset quality were constantly decreased during the study period. . The change was remarkable during 2008 and 2009. Differently at this period two unique events occurred in the banking industry. NBE implemented new directives which putted credit cup so as to reduce the amount of loan and advances in the 
economy. The second unique event in 2008 and 2009 was the spread of global financial crisis around the world.

On the other hand total investments to total asset used to measure the percentage of total assets locked up in investments against advances. This ratio were remarkably different between privet and public banks. Public banks had an erratic trend which oscillates between $30.5 \%$ and $48.4 \%$, on average $41.5 \%$. Here regardless the fashion and the amount of this huge investment, it is directed towards government projects or institutions. Whereas, private banks had almost zero investment until 2009 and then it suddenly skyrocketed to $1 \%$ in 2010 . What cases

The direct cause was, the National Bank of Ethiopia had issued a Directive "Establishment and operation of National Bank of Ethiopia Bills Market Directive No MFA/NBE BILLS/001/2011" which requires all banks in Ethiopia to purchase NBE Bills to the amount of $27 \%$ of loans and advances disbursed to rise finance for the Grate Renaissance Dam project on Nile River. The Bills had a maturity period of five years, and bear interest at the rate of $3 \%$ per annum. This directive intended to raise domestic financial resource for Grate Renaissance Dam. As per banks managers the directive crated maturity mismatch; because long term investment financed by short term deposit.

International Monitory Fund (IMF) were strongly condemned NBE as its action gradually leads banks to be insolvent. Furthermore it can negatively affected banks' profitability. Because, excluding inflation, the cost of the finance is more than $3 \%$ whereas the annual return from the bond is exactly $3 \%$. As a result IMF frequently urges NBE to slow down diverting the country finance towards its mega project so as to protect the private banks viability and the economy at large. Private banks lending to priority sectors (via NBE bills) is fixed at 3 percent, while the lending of the two state banks to priority sectors was generally well above that. DBE, for example, offers long-term loans at interest rates of about 8 percent and the CBE's most favored interest rate is offered to exporters at rates of 7 percent. As a result this provides free advantage for public banks in the cost of private banks. Other hand the banks' credit available to private sectors diverted to government mega projects.

Management Quality/Efficiency: management efficiency in customers' deposit utilization, was continuously decreased starting from 2006. The highest decrease rate scored in 2009. Why? Because, at the mid of 2009 NBE enforced credit cup on private commercial banks loan disbursement. As a result, managers were forced not to use the existing deposit efficiently and to address the alarming loan demand of their customers.

Hence the main cause at this time was not management efficiency problem. Concerning the operating efficiency of managers, which measured by the share of operating income on total revenue, it maintains a slight improvement during the last three years regardless the large investment on new technology and financial services. In addition to the above two ratios, Total revenue and Earnings before tax to the number of employee ratios were used to measure the overall quality or efficiency of managers. As per the analysis result, CBE managers were efficient and continuously improved during the study period.

Earning quality: during the study period CBE had average ROA of $4 \%$. This implies that CBE outperformed both the average ROA of Sub-Sahara countries and the international banking benchmark which was $2 \%$ and $1.5 \%$ respectively. However, if we consider inflation, both ROA and ROE of Ethiopian commercial banks could not outperform both developing countries and some international banks which have the highest scores of $10 \%$ (Keovongvichith, P 2012).

As the time series analysis revealed, CBE earning quality was hilly deteriorated exactly the year where the global financial crisis was spread throughout Africa (2008/9). For example the minimum result of ROE, which was $32 \%$, recorded was interest income to total asset ratio and ROA reached their lowest point in 2008/9.

The known reasons for earning quality decline are; firstly, in a situation where the Bank continues to record high deposit growth, credit ceiling was enforced during the first half of 2009. This provision created a strong negative impact on the contributions of credit activity to the Banks' interest income. Secondly, the decrease in interest income growth from international banking activities in which the international interest rate goes down following the financial crisis.

Liquidity: Reserve requirement was raised from $5 \%$ to $10 \%$ in July, 2007 , was further raised to $15 \%$, and liquidity requirement was also raised from $15 \%$ to $25 \%$ in April 2008. The intention of these directives did not to safe gourde the depositors or the banking industry, it is a directive to control the alarming inflation which was between 25\% \& 35 (Annual reports 2009). What so ever the motive of these directives, it improve the liquidity position of the banks. All the three liquidity ratios' maximum achieved in 2008 and 2009 following the directives.

Were commercial banks of Ethiopia liquid? Yes! Because as per the above results during 2004/5-2010/11 they can meet any sudden withdrawal measured by the share of most sensitive liability, demand deposit, and banks liquid asset. It ranges between $158 \%$ and $189 \%$ of demand deposit. The Liquid Assets to Total Assets ratio for banks account for more than 34 percent, revealing that the banks are still in a better shape of liquidity and this may be considered that the operation of banks will be stable in the future. The Liquid Assets to Total Deposits ratios, which enable banks to cover unexpected deposit withdrawals, almost indicate the same trend and it is also above the regulatory requirement with stable position. 


\subsection{Global financial crisis and CBE performance}

As evidenced from the literature, like other developing countries, Ethiopian commercial banks can be affected through international banking activities. Hence, using descriptive statistics and Paired-Samples $\mathrm{T}$ test, the following section test the hypothesis that the growth mean of the six variables before the crisis and during the crisis were not changed.

Among the growth mean deference of six variables of international banking related activities, only two variables (Deposit in Foreign Banks and Gain from Foreign Currency Translation and Exchange) had positive growth mean during the global financial crisis, but the change was not statistically significant at $1 \%$ significance level. Whereas loan dispersed for importers (LI), interest income from foreign deposit, ROA, total revenue from international banking actives had been decreased by $214 \%, 217 \%, 16 \%$ and $39 \%$ respectively.

Figure 1: Paired-Samples $T$ test results of international banking related activities variables

\begin{tabular}{|l|r|r|r|r|r|}
\hline \multicolumn{7}{|l|}{ After-Befor tests } \\
\hline Paired-Samples T test results & \multicolumn{1}{|c|}{ t } & Sig. (2-tailed) \\
\hline \multicolumn{1}{|c|}{ Variables } & \multicolumn{1}{|c|}{ Mean } & Std. Deviation & Std. Error & \multicolumn{1}{c|}{ t } & $.001^{*}$ \\
\hline ALI - BLI & -214.313 & 84.857014 & 32.072937 & -6.682 & 0.923 \\
\hline AFD - BFD & 2.391695 & 57.396084 & 23.431853 & 0.102 & $.013^{*}$ \\
\hline AIIFD - BIIFD & -217.127 & 140.477328 & 57.349629 & -3.786 & $0.032^{*}$ \\
\hline ATR - BTR & -39.3953 & 76.159025 & 34.059351 & -1.157 & 0.672 \\
\hline AGFCTE-BGFCTE & 6.143239 & 30.083095 & 13.453569 & 0.457 & $0.041^{*}$ \\
\hline AROA - BROA & -15.831 & 35.613098 & 19.782051 & -1.642 & 0 \\
\hline
\end{tabular}

*significance at $5 \%$

As of the Paired-Samples T test results, loan dispersed for importers (LI) decreased on average by $214 \%$ and it is statistically significant at 5\% level. This implies that commercial banks of Ethiopia faced a significant shortage of foreign currency to finance importers. Secondary data showed that the country's foreign exchange reserve, which used to cover more than three months of imports, fell to cover only around one month of import during 2008/9. The result is consistent with the banks' annual reports which disclosed the global financial crisis reduced banks' ability to meet the foreign exchange needs of their importing clients adequately. Thereby it lowered the contributions of import activities to the Banks' overall income.

The interest income significantly decreased by $217 \%$. This was the direct consequences of international interest rate fluctuation and decline. Consequently, total revenue generated from international banking activities on average reduced by $39 \%$, which was statistically significant at 5\% significance level. Also Commercial Banks of Ethiopia Return on Asset average growth declined by 16\% during the global financial crisis, the decline was statistically significant at 5\% significance level.

Regarding GFCTE, the global financial crisis positively affected the banks earning on average by $6 \%$ but it was not statistically significant at 5\%. The possible reason was the depreciation of Ethiopian Birr against United States Dollar.

\section{Conclusions}

Following the double digit economic growth of Ethiopia, credit demand by private sectors become rampant. This allows banks to mobilize their finances to the credit starved private sectors. On the other hand, the iterance of new banks, innovation of new technology and new financial services are the main character of Ethiopian commercial banks during the study period. Thus, the industry becomes more competitive than ever. These lead banks to take risky banking activities and it raise the level of RWA. As a result Capital Adequacy of commercial banks of Ethiopia slightly deteriorated during the study period. Despite this, the banks have maintained the National Banks of Ethiopia Capital Adequacy requirement.

The banks' asset quality significantly improved following the NBE directives on banks credit limit since 2008/9. Relatively commercial banks of Ethiopia maintain more quality assets compared with the international standard and SSA countries. Regarding investment on NBE bills and other government securities, public banks take the lion share through channeling resources from private sectors to government mega projects. Whereas private banks had almost zero investment until 2009/10 and then it suddenly skyrocketed to $11 \%$ in 2010 following National Bank of Ethiopia Bills Market Directive No MFA/NBE BILLS/001/2011.

As of IMF Report, this directive lead banks to be insolvent, erode credit availability for private sectors and it could negatively affect banks' profitability. Because excluding inflation, for private sectors, the cost of the finance is more than 3\% whereas the annual return from the bond is exactly $3 \%$.

Managers' efficiency in deposit mobilization significantly deteriorates in 2008/9. Because, credit cup on private commercial banks loan disbursement were forced managers not to use the existing deposit efficiently to address the alarming loan demand of their customers. Concerning the operating efficiency of managers, they 
maintains improvement regardless the large investment on new technology and financial services. Commercial banks of Ethiopia earning quality measured by ROA and ROE, it was greater than developing countries and some international banks. However if we consider inflation, both ROA and ROE of Ethiopian commercial banks more or less in line with SSA countries and the standard level.

According to the study findings Commercial banks of Ethiopia are liquid. Because, measured by ratio of the most sensitive liability to banks liquid asset, they can meet any sudden withdrawal. Also the Liquid Assets to Total Assets ratio for banks account for more than 34 percent, revealing that the banks are still in a better shape of liquidity and this may be considered as the operation of banks will be stable in the future. The Liquid Assets to Total Deposits ratios, which enable banks to cover unexpected deposit withdrawals, almost indicate the same trend and it was above regulatory requirement with stable position. The above three liquidity ratios' maximum achieved in 2008/9 following reserve requirement raise from 5\% to $10 \%$ in July, 2007, was further raised to $15 \%$, and liquidity requirement raise from $15 \%$ to $25 \%$ in April 2008. Fortunately, reserve requirement reduction enacted in early January 2012 by $5 \%$.

Hence, during the financial crisis, shortage of foreign exchange earnings significantly reduced commercial banks of Ethiopia ability to meet the foreign exchange needs of their importing clients adequately. Thereby it lowered the contributions of import activities to the Banks' overall income. Also interest income from foreign deposit significantly decreased during the financial crisis. Hence the null hypothesis there were no change in the mean growth of loan to importers and interest income from foreign deposit before and during the crisis are rejected.

On the other hand, the accelerated depreciation of the Birr led to higher gains in foreign exchange dealings than usual by scoring $6 \%$ growth. This slightly compensated for low interest earnings. Total revenue from international activities and return on asset growth significantly decreased by $39 \%$ and $16 \%$ respectively. Thus, the null hypothesis there is no significant change on the growth of Return on Asset and there is no significant change on the growth of total revenue from international activities before and during the crisis have been rejected. Therefore, despite CBE were owned by state and domestic investors and international banks has been prohibited to operate in Ethiopia; the financial crisis had significantly affected the banking industry financial performances.

\section{References}

Adamu A.(2009), The effects of Global Financial Crisis on Nigeria Economy, Adamuabdulmumeen@yahho.com

Ashamu (2012). The Impact of Global Financial Crisis on Banking Sector in Nigeria British Journal of Arts and $\begin{array}{llllll}\text { Social Sciences } & \text { ISSN: } & 2046-9578, & \text { Vol.4 } & \text { No.2 } & \text { (2012) }\end{array}$ CBritishJournalPublishing,Inc.2012retrievedfromhttp://www. bjournal. co. uk/BJA SS.aspxAtrium, Southern Gate, Chichester, West Sussex PO19 8SQ.

Field A (2005), Discovering Statistics Using SPSS. (2nd eds). Sage publications, United Knigdom. pp. 63-65 Karande, S.B. (2012) Global Economic Crisis-Impact on Indian banking sector, global economic research halfyearly research journal, ISSN 2249- 4081

Keovongvichith, P. (2012), An Analysis of the Recent Financial Performance of the Laotian Banking Sector during 2005-20 10. International Journal of Economics and Finance Vol. 4, No. 4; April 2012

Kiyota, H. (2009), Efficiency of Commercial Banks in Sub-Saharan Africa: A Comparative Analysis of Domestic and Foreign Banks. A paper prepared for presentation at the CSAE conference 2009 on "Economic Development in Africa " to be held at the University of Oxford from 22nd to 24th March 2009

Karande, S.B. (2012), Global Economic Crisis-Impact on Indian banking sector, global economic research halfyearly research journal, ISSN 2249- 4081

Kumbirai and Webb (2010), Financial Ratio Analysis of Commercial Bank Performance in South Africa, African Review of Economics and Finance, Vol. 2, No. 1, Dec 2010 CThe Author(s) Journal compilation (C)2010 African Centre for Economics and Finance. Published by Print Services, Rhodes University, P.O. Box 94, Graham town, South Africa.

Mwega F. M. (2010), Global Financial Crisis Discussion Series Paper 17: Kenya Phase 2, Overseas Development Institute 111 Westminster Bridge Road London SE1 7JDOsakwe (2010)

Osakwe, 2010 Osakwe, P. (2010), African and the Global Financial and Economic Crisis: Impacts, Responses and Opportunities United nation publication, Sales No. e.11.II.D.11 ISbN 9 78-92-1-112818

Prasad, K. V. N. (2011), Evaluating performance of public and private sector banks through CAMEL model. Asian Journal of Research in Banking and Finance 2(3). Retrieved from $<$ http://www.aijsh.org/setup/banking/paper171.pdf $>$.

Reddy,S. (2012), Relative Performance of Commercial Banks in India using CAMEL. Research journal of $\begin{array}{lllll}\text { economics and } & \text { business } & \text { Retrieved } & \text { from }\end{array}$ $<$ http://www.theinternationaljournal.org/ojs/full/vol01no04_rjebs.pdf $>$ 
Reddy, M. Prasad, K.V.N. (2011), Evaluating Performance of Regional Rural Banks: A Application of CAMEL Model. International Refereed Research Journal II (4). Retrieved from $<$ http://www.researchersworld.com/vol2/issue4/Paper 7.pdf $>$

Samad, A. (2004), Bahrain Commercial Banks Performance during 1994-2001. Credit and Financial Management Review 10(1) pp 33-40.

Sinkey, J. (2002), Commercial Bank Financial Management: In the Financial- Services Industry 6th Edition Prentice Hall, Upper Saddle River, NJ.

Tarawneh, M. (2006), A comparison of financial performance in the banking sector: some evidence from Omani commercial banks, International Research Journal of Finance and Economics, vol. 3, pp. 101-112.

Webb, R.M. (2003), Levels of efficiency in UK retail banks: a DEA window analysis. International Journal of the Economics of Business Vol 10 (3), pp 305-322.

Appendix: A

\begin{tabular}{|c|c|c|c|c|c|}
\hline \multirow{3}{*}{\begin{tabular}{|l} 
CAMEL \\
C \\
\end{tabular}} & \multicolumn{5}{|c|}{ Performance analysis, CAMEL Model } \\
\hline & \multicolumn{5}{|c|}{ Capital Adequacy } \\
\hline & & Max & Mini & Average & SD \\
\hline & TC/RWA & 16.44 & 8.94 & 16.44 & 0.030097 \\
\hline & TD/TA & 87.67 & 85.63 & 87.67 & 0.007853 \\
\hline & Teir1/TA & 12.45 & 7.98 & 12.45 & 0.018351 \\
\hline \multirow[t]{5}{*}{$\mathbf{A}$} & \multicolumn{5}{|l|}{ Asset Quality } \\
\hline & & Minimum & Maximum & Mean & SD \\
\hline & AFDL/Netloanout. & 4.54064 & 8.761462 & 6.271454 & 0.015019 \\
\hline & AFDL/TA & 1.819411 & 3.534472 & 2.91696 & 0.007469 \\
\hline & NPLs/Net loan out. & 0.435688 & 1.771327 & 1.154653 & 0.005814 \\
\hline \multirow[t]{4}{*}{$\mathbf{M}$} & \multicolumn{5}{|c|}{ Management Quality/Efficiency } \\
\hline & & \begin{tabular}{|l|l|} 
Aver. \\
\end{tabular} & Max & Mini & SD \\
\hline & LO/TD & 67.01839 & 82.51135 & 50.80197 & 0.115969 \\
\hline & EBT/TR & 50.57406 & 53.71937 & 44.90457 & 0.02593 \\
\hline \multirow[t]{5}{*}{$\mathbf{E}$} & \multicolumn{5}{|l|}{ Earning quality } \\
\hline & & Minimum & Maximum & Mean & SD \\
\hline & ROA & 3 & 4.5 & 4 & 0.002739 \\
\hline & ROE & 32 & 46 & 39 & 0.046177 \\
\hline & II/TR & 51 & 62.3 & 57.6 & 0.0475 \\
\hline \multirow[t]{6}{*}{$\mathbf{L}$} & \multicolumn{4}{|l|}{ Liquidity } & \\
\hline & & Max & Mini & SD & \\
\hline & LA/TA & 51.71021 & 34.09777 & 0.066877 & \\
\hline & LA/TD & 59.49346 & 44.05786 & 0.065537 & \\
\hline & LA/DD & 188.7438 & 158.159 & 0.109693 & \\
\hline & Source: researcher & computatio & on using SPSS & & \\
\hline
\end{tabular}

Appendix: B

\begin{tabular}{|l|r|r|}
\hline \multicolumn{3}{|c|}{ One-Sample Kolmogorov-Smirnov Test } \\
\hline & $\begin{array}{l}\text { Kolmogor } \\
\text { ov- } \\
\text { Smirnov Z }\end{array}$ & $\begin{array}{l}\text { Asymp. Sig. (2- } \\
\text { tailed) }\end{array}$ \\
\hline Variables & 0.633 & 0.818 \\
\hline FD & 0.447 & 0.988 \\
\hline IIFD & 0.416 & 0.995 \\
\hline TRIA & 0.654 & 0.786 \\
\hline GFCTE & 0.482 & 0.975 \\
\hline ROA & 0.685 & 0.735 \\
\hline Source: researcher computation using SPSS \\
\hline
\end{tabular}

